THURSDAY，MARCH $19 ， 1885$

\section{THE DEBATE ON VIVISECTION AT OXFORD}

T our last issue we gave a brief notice of the proceed-

ings in an overflowing Convocation at Oxford, which resulted in a majority of 412 votes to 244 in favour of the decree promulgated by the Hebdomadal Council. This decree had only an indirect bearing upon the question of vivisection; but as it was made an occasion for a fresh, and, let us hope, a final trial of strength between the scientific and anti-scientific forces of the University, it is desirable to furnish our readers with a somewhat more full account of what took place than we had time to print last week. Seeing that the debate had clearly been organised with no small amount of care on the side of the anti-vivisectionists, and that the ablest as well as the most authoritative speakers in Oxford who could support their cause were put forward, we may regard the arguments which were adduced as a fair example of the best that can be said against vivisection by cultured thought and cultured speech. We will therefore confine our remarks to what was said on this side of the question.

Regarded as a piece of oratory, the speech of Canon Liddon was, in our opinion, perfect; and the effect of what we may term an artistic eloquence was enhanced by the appearance and costume of the speaker, as well as by the appropriateness of his surroundings in the densely crowded Sheldonian Theatre. But when we look from the manner to the matter of his speech, we are unable to bestow such unqualified praise, although we confess that even here we were agreeably surprised by the judicious moderation of its tone. His views, briefly stated, were that so long as we hold it morally lawful to kill animals for food, or otherwise to use them for our own purposes, so long must we in consistency hold that, under certain circumstances, it is morally lawful to inflict pain upon animals for the benefit of man: the special case of vivisection does not differ in principle from other cases where pain is thus inflicted; but it ought to be qualified by three conditions-it should be resorted to as rarely as possible, it should be guarded against the instinct of cruelty, and it should be so used as not to demoralise spectators. With all this every physiologist would of course agree. The Canon, however, proceeded to talk what in the strictest meaning of the word must be termed nonsense, when he affirmed that physiology might be "divorced" from vivisection. That this statement has gained currency among the anti-vivisectionists does not alter its essentially unreasonable character. It is perfectly true that in many departments of physiological research vivisection is not required; but it is no less true that in many other departments vivisection is an unconditional necessity. This fact, one would think, admits of being rendered obvious to any impartial mind, howsoever ignorant of physiological science. For if this science consists in the study of vital processes going on in the living organism, does it not obviously follow that some of them can only be studied while actually taking place? How, for example, would it be possible to gain any knowledge of the electrical and other changes which occur in a gland during the process of secretion, except by estiVOL. XXXI.-No. 803 mating these changes during the act of secretion? The gratuitous information which physiologists receive from technically ignorant sources touching the nature and the value of their own methods, can only suggest the presumption of inexperienced youth when verituring to instruct a maternal grand-parent in the practical aspects of oology.

It appears that Prof. Burdon-Sanderson had pledged himself not to exhibit vivisections to his class for the purposes of teaching, and for this concession to the unreasoning prejudice of his opponents he received a warm expression of gratitude from Canon Liddon. Probably enough, under the circumstances in which he is placed, the concession is a prudent one; but that it merited the eulogium which was bestowed upon it by Canon Liddon on moral grounds, no man of common sense could very well suppose. Demonstrations on the living subject, if performed in a class-room at Oxford, would of course be always performed on animals under the influence of anæsthetics; and therefore the "demoralising" effects upon the minds of young men, which Canon Liddon takes to have been averted by Prof. Sanderson's concession, can only be understood to consist in disregarding the mawkish sentimentality which cannot stand the sight of a painless dissection. This kind of "morality" may be regarded as tolerable in a girl: in a man it is not tolerable, and deserves the same kind of pitying contempt as is accorded to personal cowardice, with which it is most nearly allied.

Canon Liddon, however, regretted that Prof. Sanderson had not further pledged himself to restrict his experiments for the purposes of research to animals kept under the influence of anæsthetics during the operations, and killed before recovering from their anæsthesia. We have no doubt that Prof. Sanderson might have complied with the first of these suggestions without any serious detriment to his future researches. For, as a matter of fact, the cases in which anæsthetics interfere with the progress of an experiment are, comparatively speaking, very rare indeed, except where the occurrence of pain forms a necessary part of the experiment-i.e. in certain researches on the functions of sensory nerves. But as all the functions of sensory nerves which require for their study the infliction of pain have already been worked out, physio$\log y$ as it now stands does not demand the absence of anæsthetics, save in a very small per centage of operations. Therefore, when pain is inflicted during an operation, it is due, as a rule, not to the exigencies of research, but to the indifference of the operator-a fact which we think physiologists ought to be more insistant than they are in impressing upon the mind of the public. Nevertheless, we feel persuaded that Prof. Sanderson was perfectly right in not binding himself never to operate without anæesthetics; for by so doing he would have virtually conceded the principle that the suffering of an animal is too great a price at which to buy an advance of knowledge; and this, among other things, would have been to place a moral stigma upon some of the most valuable researches of the past. Besides, as was pointed out in the course of an able speech by Prof. Dicey, it is not desirable that the status of a Professor in the University should be regarded as beneath that of a gentleman; and if it is supposed that Dr. Sanderson is not to 
be trusted in the latter capacity, he ought never to have bcen chosen to fill an Oxford chair. In short, as the representative of physiology in Oxford, Dr. Sanderson, by the nature and extent of his concession, has drawn a clear distinction between the importance of teaching and of research: he has consentcd to allow the teaching to suffer if needs be ; but he will not consent to yield an inch where the principles of research are concerned.

The other suggestion which was thrown out by Canon Liddon-namely, that a Professor of Physiology ought to pledge himself to kill every animal before it recovers from its anæesthesia-is, from every point of view, absurd. In the first place, the suggestion can only emanate from the uninformed supposition that the pain of a healing wound is considerable. But we know from the experience of hospital practice that even the most severe wounds are painless while healing, unless the process of healing is complicated by morbid conditions, which now admit of being wholly prevented by antiseptic methods. As a matter of fact, therefore, in our physiological laboratories, as in our surgical wards, there is at the present time but an extremely small amount of suffering to be found in connection with the healing of wounds; and no man of ordinary sense who had ever seen the inside of either the one or the other would have cared to make the suggestion which we are considering. But, in the next place, even if this were not so, it would thave been highly wrong in any Professor of Physiology to restrict himself to the performance of cxperiments the objects of which could be secured during the action of an anasthetic. Certainly more than half the experiments which the physiologist has now to perform have reference to questions of aftereffects, and this is especially the case in experiments bearing upon the problems of pathology.

The speech of the I3ishop of Oxford was bad, both in logic and in taste. It was bad in logic because in arguing for the total suppression of physiological research in Oxford, he relied upon foreign practice for his evidence of cruelty. This was essentially illogical, because it fails to distinguish between two very different things-namely, the cruelty, if any, which attaches to vivisection per se, and the cruelty which arises from other sources. If the state of public feeling in some foreign countries is not so sensitive as it is in our own on the matter of inflicting pain upon the lower animals, it is obviously unfair to search through the Continent for instances of cruelty in connection with physiological research, and then to adduce such instances as proof of cruelty necessarily attaching to physiological research at home. We might as well argue against the use of mules in England because these animals are badly treated in Spain. As we have already said, there are now but extremely few cases possible in which the occurrence of pain is necessary for the purposes of an expcriment; and therefore the proof of pain having been inflicted in any one case constitutes proof, not of the pain-giving character of vivisection in general, but of the carelessness of some operator in particular. The cruelty must belong to the individual, not to the methods; and we are not aware that any charge of cruelty has hitherto been proved against an English physiologist.

The Bishop of Oxford's speech was bad in taste, because he sought, missionary-wise, to tell some anecdote of horror, which the good sense of Convocation prevented him from narrating further than that the subject of his story was to have been "an affectionate little dog." But, as he was not able to give any reference to the scene of his tragedy, after a prolonged battle with his audience upon this somewhat necessary proof of authenticity, he was obliged to give way. His taste was perhaps still more questionable when, in the presence of Prof. Sanderson and other working physiologists, he proceeded to adduce the favourite argument that the pursuit of experimental physiology exercises a baleful influence on the moral nature. That the argument is unsound, both in principle and in fact, we need not wait to show.

The speech of Prof. Freeman was rendered wholly inaudible by a general uproar, which proceeded chiefly from the side which he rose to support. We were told that this was due to the memory of the effect which was produced by his speech on the occasion of the previous vote.

Upon the whole we think that the debate was of no little service to the cause of physiology in Oxford; and when we consider how largely the majority of votes has grown since the first of the three divisions, we are glad to congratulate the University upon having shown so emphatically that, not less than her sister, she is able to withstand the assaults of the two great enemies of learning--Ignorance and Fanaticism.

\section{THE RELATIVE EFFICIENCY OF WARSHIPS}

I $N$ our last week's issue we published a letter from Sir

Edward Reed adverting to some points in an article which appeared in our number of February 26 upon "The Relative Efficiency of War Ships." In order to show the difference existing between the ships of the Inflexible or Agamemnon class and those of the Admiral class, as regards height of armour above the water, we then gave profiles of the Agamemnon and of the Collingwood (one of the Admiral class). We now give outline sections of the same vessels, in which this large difference can be more clearly seen, and by means of which its importance can be better understood.

Before giving any figures in connection with this question it may be as well to mention another point which, taken alone, is not unworthy of notice. We refer to the difference betwcen the Agamemnon and Collingwood with regard to depth of armour below the water. When the Agamemnon is floating in smooth water, with her unarmoured ends uninjured, the depth of her armour below the water-line is 5 feet ro inches, whereas that of the Collingwood, under the same conditions, is only 5 feet, as shown in Figs. I and 2 respectively. This difference of nearly $\mathrm{I}$ foot is of some importance, because every two or three inches gained in depth of armour below the water means a large increase in the safety of the ship when fighting at sea. When the ends of the Agamemnon are flooded she sinks 22 inches deeper in the water, and the depth of her armour below its surface would, therefore, then be 7 feet 8 inches (Fig. 3). The Collingwood, when her ends are flooded, sinks $17 \frac{1}{2}$ inches deeper in the water, and in that condition, therefore, her armour would be 6 feet $5_{2}^{\frac{1}{2}}$ inches below the water's surface (Fig. 4), or I foot $2 \frac{1}{2}$ inches less than that of the Agamemnon. In the earlier ironclads it was considered necessary to carry 